\title{
The behaviour of drifted Cape honeybee workers (Apis mellifera capensis): predisposition for social parasitism?
}

\author{
Peter NeUmanN ${ }^{\mathrm{a}, \mathrm{c} *}$, Sarah E. RADLOFF ${ }^{\mathrm{b}}$, Christian W.W. PIRK $^{\mathrm{c}, \mathrm{d}}$, Randall HEPBURN $^{\mathrm{c}}$ \\ a Martin-Luther-Universität Halle-Wittenberg, Institut für Zoologie, Kröllwitzer Str. 44, 06099 Halle/Saale, \\ Germany \\ b Department of Statistics, Rhodes University, Grahamstown 6140, South Africa \\ ${ }^{c}$ Department of Zoology and Entomology, Rhodes University, Grahamstown 6140, South Africa \\ d Lehrstuhl für Verhaltensphysiologie und Soziobiologie, Zoologie II. Biozentrum der Universität Würzburg, \\ Am Hubland, 97074 Würzburg, Germany
}

(Received 26 September 2002; revised 14 April 2003; accepted 25 April 2003)

\begin{abstract}
Cape honeybee workers are facultative social parasites and drifting is one mode of transmission to new host colonies. The behavioural patterns and spatial distributions of drifted Cape honeybee workers differed from those of non-drifted workers of the same age cohort. Drifted workers were significantly more idle and were more often found in areas away from the queen compared to non-drifted workers. Our data suggest that drifted Cape honeybee workers may be predisposed for social parasitism in host colonies.
\end{abstract}

Apis mellifera capensis / drifting / honeybee / social parasitism / worker reproduction

\section{INTRODUCTION}

Laying workers of the Cape honeybee, Apis mellifera capensis Escholtz, are facultative social parasites (Neumann and Hepburn, 2002; Neumann and Moritz, 2002) and individual workers can enter new host colonies by drifting (Neumann et al., 2001b). Drifting results from orientation errors of young workers during their orientation flights and of returning foragers (Rauschmayer, 1928; Free, 1958; Pfeiffer and Crailsheim 1998; Neumann et al., 2000). However, very few studies address the actual behaviour of drifted workers in host colonies. This is of prime importance with respect to social parasitism because the behaviour of drifted workers may govern whether an individual can reproduce in the host colony or not.
Drifted A. m. carnica workers are generally more inactive and seem to perform tasks of importance for the colony less frequently than those related to individual welfare such as receiving food or being groomed (Pfeiffer and Crailsheim, 1999). Similarly, reproductively dominant Cape honeybee workers do not participate as much in hive duties compared to subordinate ones (Hillesheim et al., 1989). Since the life expectancy of workers is related to work load (Woyke, 1984) and to individual reproductive success (Neumann and Moritz, 2002), inactivity of drifted workers might actually constitute a tactic to increase individual fitness (Pfeiffer and Crailsheim, 1999). This is especially the case, if successful reproduction of social parasitic A. m. capensis workers is more likely during certain time windows such as major pollen flows (A. Schehle, personal

\footnotetext{
* Corresponding author: p.neumann@zoologie.uni-halle.de
} 
communication), supersedure events or after queenloss (Härtel, Moltzer, Neumann and Hepburn, unpublished data).

Given that drifted Cape honeybee workers follow a tactic of "hopeful" reproductives in their new host colonies, other mechanisms also come into play. In particular, the development of queen-like pheromones appears to be an essential part of the social parasitic pathway of $A$. m. capensis workers (Wossler, 2002; Neumann and Hepburn 2002). However, the pheromonal bouquet of the host queen might suppress the ovarial development of the drifted workers unless they already show some pre-drifting ovarial development (Reece, 2002; Neumann and Hepburn, 2002). One mechanism to avoid the suppressive signals of the host queen may be simply to evade the queen's mandibular gland signals and remain in areas of low 9-ODA concentration in the colony (Neumann and Moritz, 2002). Such behaviour is more readily expressed in A. $m$. capensis workers than in the neighbouring subspecies $A$. m. scutellata (Moritz et al., 2001) and those workers staying away from the queen show a more queenlike pheromonal bouquet (Moritz et al., 2002). However, it is unknown whether drifted Cape honeybee workers show a stronger tendency to stay away from the queen compared to nondrifted bees. Given that drifted A. m. capensis workers are less active and more frequently stay away from the queen, this would suggest that such workers are predisposed for social parasitism in their host colonies. Here we study the behaviour of drifted and non-drifted Cape honeybee workers.

\section{MATERIALS AND METHODS}

\subsection{Sampling and experimental design}

Five unrelated queenright colonies of A. $m$. capensis (each $~ 3000$ bees) were placed in three-frame observation hives $1 \mathrm{~m}$ apart from each other at Rhodes University, Grahamstown, South Africa. In order to reduce the potential impact of different hive environments on the drifting of workers, all observation hives were provided the same experimental set up. The middle frame in each hive contained brood and the top and bottom frames honey and pollen; while food and water were provided ad lib. Flight entrances were labelled with the same colour to amplify orientation errors (Rauschmayer, 1928). Parallel to the setting of the observation hives, frames with sealed worker brood were taken from each of the experimental colonies and placed in an incubator until adult emergence. Freshly emerged workers $(\mathrm{N}=400$ of the same age cohort for each colony) were individually marked using a combination of Opalithplättchen on the thorax and a colony specific colour code on the abdomen. Then, the marked workers were simultaneously reintroduced into their mother colonies.

\subsection{Behavioural observations}

Behavioural observations started 12 hours after the introduction of the labelled workers. A grid was drawn on the side panes of each observation hive, dividing the frames into 10 columns and 16 rows $(5 \times 5 \mathrm{~cm})$. The behaviours and positions of all labelled workers and of the resident queens were recorded twice daily for each colony from $09 \mathrm{~h} 00$ $12 \mathrm{~h} 00$ and $15 \mathrm{~h} 00-18 \mathrm{~h} 00$ for 24 days on both frame sides. Because honeybees show a daily activity rhythm being less active at night (Moritz and Kryger, 1994), this might have interfered with data accuracy; however, all behavioural observations were performed during daylight when normal flight activity occurs. Moreover, all workers belonged to the same age cohort and cycling was the same for drifted and non-drifted workers. Finally, behavioural observations started with alternating colonies on subsequent days (day one: colony 1 , day two: colony 5 ; day three: colony 2 , day four: colony 4 , etc.). Task performances were allocated to two categories: (a) being idle (staying motionless on the comb) or (b) being active (performing any other task than being idle). The positions of individual workers in relation to the queens in the observation hive colonies were determined using a discrete geodesics model (Neumann et al., 2001a). Behavioural observations were performed blindly with respect to the objectives of the study.

\subsection{Data analysis}

Proportions of being idle and active were determined on a cohort level (drifted vs. non-drifted bees) and on an individual worker basis. We used mean queen-worker distances on an individual worker basis. Differences in total activity between drifted and non-drifted bees and mean queenworker distances for individual bees were analysed with Mann-Whitney U tests. Z-tests of proportions were used to test for differences in the task performances of whole cohorts between drifted and nondrifted workers. Behavioural data for both worker activity and worker-queen distances were only analysed from experimental day 5 onwards because 
Table I. Total distribution of drifted and nondrifted workers per host colony.

\begin{tabular}{lccc}
\hline Colony & Non-drifted & Drifted & Total \\
\hline 1 & 355 & 20 & 375 \\
2 & 293 & 138 & 431 \\
3 & 274 & 21 & 295 \\
4 & 276 & 82 & 358 \\
5 & 265 & 71 & 336 \\
\hline Total & 1463 & 332 & 1795 \\
\hline
\end{tabular}

most workers performed their orientation flights and drifted within a five day time window. Differences between colonies with respect to activity levels and worker-queen distances were tested using Kruskal Wallis tests. In case colonies differed significantly, all calculations were performed excluding these particular colonies to ensure that differences between colonies were not affecting the results for the drifted and non-drifted bees.

\section{RESULTS}

A total of 332 labelled workers drifted into foreign colonies (Tab. I). The extent of drifting ranged from $5 \%$ to $32 \%$ with a mean of $17.8 \% \pm 11.2 \%$. A total of $\mathrm{N}=22897$ individual behavioural acts and $\mathrm{N}=1732$ mean queenworker distances were recorded (Tab. II). When comparing whole drifted and non- drifted cohorts, drifted workers were significantly more idle (Tab. II). Similar results were obtained when comparing drifted and nondrifted workers on an individual basis (Tab. II).

Non-drifted workers had a mean distance of $33.59 \pm 10.97 \mathrm{~cm}(\mathrm{~N}=1436)$ to the queens. However, drifted workers had a significantly higher distance of $37.03 \pm 14.87 \mathrm{~cm}(\mathrm{~N}=296)$ to the resident queens (Mann-Whitney U-test: $\mathrm{Z}($ approximation $)=3.47, P<0.001)$. Significant differences were found in the proportions of being active/idle and queen-worker distances between the five colonies (active/idle: Kruskal Wallis $\mathrm{H}=136.7$ with $(4,1775) \mathrm{df}$, $P<0.01$; distance: $\mathrm{H}=81.1$ with $(4,1732) \mathrm{df}$, $P<0.01$ )

Multiple comparison tests revealed, however, that only one colony (active/idle: colony 5; distance: colony 3 ) differed significantly from the other four colonies in the proportions of being active/idle and queenworker distances. Repeated analyses on proportions of being active/idle and queenworker distances using four colonies again found drifted workers to be significantly more idle and further away from the queen compared to non-drifted workers (non-drifted workers $(\mathrm{N}=1185)$ : idle $53.16 \%$, drifted workers $(\mathrm{N}=295)$ : idle $57.04 \%, \mathrm{Z}=2.12$, $P<0.05$; non-drifted workers $(\mathrm{N}=1162)$ : queen-worker distance $33.05 \pm 11.17$, drifted workers $(\mathrm{N}=275)$ : queen-worker distance

Table II. Comparisons of percentages of being active/idle for drifted and non-drifted workers. Significant results are indicated with $* *$ for $P<0.001(P=$ significance level $)$.

\begin{tabular}{|c|c|c|c|c|c|c|}
\hline & \multicolumn{2}{|c|}{ Non-drifted } & \multicolumn{2}{|c|}{ Drifted } & $\mathrm{Z}$ & $P$ \\
\hline & $\begin{array}{c}\text { No. of } \\
\text { behavioural acts }\end{array}$ & $\%$ & $\begin{array}{c}\text { No. of } \\
\text { behavioural acts }\end{array}$ & $\%$ & & \\
\hline Active & 9548 & 46.75 & 1070 & 43.23 & 3.32 & $* *$ \\
\hline Idle & 10874 & 53.25 & 1405 & 56.77 & -3.32 & $* *$ \\
\hline Total & 20422 & 100.00 & 2475 & 100.00 & & \\
\hline \multicolumn{7}{|c|}{ Individuals } \\
\hline & No. of workers & $\%$ & No. of workers & $\%$ & & \\
\hline Active & 1459 & 49.82 & 316 & 43.86 & 3.81 & $* *$ \\
\hline Idle & 1459 & 50.18 & 316 & 56.14 & -3.81 & $* *$ \\
\hline
\end{tabular}


$36.86 \pm 14.77$, Mann-Whitney U-test: Z $($ approximation $)=3.61, P<0.0001)$.

\section{DISCUSSION}

A much higher proportion of workers drifted into foreign colonies than in previous studies on African bees ( 5\% Neumann et al., 2001b). Thus, our experimental design amplified the number of orientation errors to a great extent, suggesting that the underlying mechanisms for orientation errors are very similar between Cape bees and European honeybees.

Because all experiments were performed in observation hives, the results could have a limited interpretational range regarding the assessed behaviours due to the different architecture of human made hives and natural multi-comb nests. However, this appears less relevant for the present study which addresses drifting, a behaviour which is rare (if not absent) between natural nests but abundant in apiaries (Neumann et al., 2001b).

Although the absolute differences were low for both activity levels and queen-worker distances, we nevertheless found highly significant differences between drifted and nondrifted workers. Thus, our data for Cape bees is consistent with earlier findings for $A$. $m$. carnica that drifted workers are less active in their new host colonies (Pfeiffer and Crailsheim, 1999). Behavioural activity of workers is related with their longevity (Woyke, 1984) and the reproductive output of individual workers (Neumann and Moritz, 2002). Moreover, drifted workers showed a higher mean distance towards the queen compared to non-drifted workers. Workers staying away from the queen produce more queenlike compounds in the mandibular gland secretions and this is consistent with the interpretation that they have further differentiated into reproductives than others (Moritz et al., 2002). Furthermore, worker policing (the removal of worker-laid eggs by other workers) is less well expressed in areas away from the queen in both queenright colonies of $A$. $m$. scutellata and $A$. $m$. capensis which appears to facilitate social parasitism by laying Cape honeybee workers (Neumann et al., 2003). Therefore, it appears as if drifted Cape honeybee workers are predisposed for social parasitism. Such a predisposition might be amplified by orders of magnitude when $A$. $m$. capensis workers drift into host colonies of susceptible subspecies such as the neighbouring one A. $\mathrm{m}$. scutellata.

Given there is a true causative connection between drifting and subsequent behaviour, the question remains why drifted workers are less active and why there is a greater mean distance between drifted bees and the queen. One possible explanation for higher idleness could be that drifted workers are less stimulated by normally recognized signals in the colony (Seeley, 1998) and are rather less sensitive to stimuli cues in the colony (Seeley, 1998) than non-drifted workers. With respect to greater mean distance between drifted bees and the colony-right queen several explanations are possible. For example, it might well be that drifted workers actively avoid the queen to retain their reproductive capacity. Alternatively, but not mutually exclusive, it could well be that drifted workers try to go just far away from the outlet of the hive, or that drifted workers simply climb more up the combs in the hives than non-drifted ones. In any case, the actual mechanisms underlying the postdrifting behaviour of honeybee workers remain unclear and require further investigations.

We conclude that drifting constitutes not only one mode of host finding for social parasitic Cape honeybee workers (Neumann et al., 2001b; Neumann and Hepburn, 2002; Neumann and Moritz, 2002) but may also play an important role for the individual fate of such workers inside of the host colonies.

\section{ACKNOWLEDGEMENTS}

We are grateful to A. Bownes and A.J. Solbrig for technical assistance. H.M.G. Lattorff made valuable comments on an earlier version of the manuscript. Financial support was granted by a Rhodes University fellowship and an Emmy Nöther fellowship of the DFG to PN and the DAAD to CWWP.

Résumé - Le comportement des ouvrières de l'Abeille du Cap (Apis mellifera capensis) qui ont dérivé : une prédisposition au parasitisme social ? Les ouvrières pondeuses de l'Abeille du Cap (Apis mellifera capensis Escholtz) sont des parasites sociaux facultatifs et la dérive constitue un mécanisme pour trouver l'hôte. On connaît peu de 
choses sur le comportement dans les colonies hôtes des abeilles qui ont dérivé. L'activité et la répartition spatiale dans la colonie peuvent jouer un rôle dans le parasitisme social par les ouvrières pondeuses, puisque des ouvrières inactives ont une durée de vie plus longue et que les abeilles qui se tiennent plus éloignées de la reine ont une sécrétion phéromonale plus développée. L'activité et la répartition spatiale par rapport à la reine d'ouvrières du Cap ayant ou non dérivé ont été suivies dans cinq ruches d'observation, comprenant chacune environ 3000 ouvrières. Des abeilles fraîchement écloses ont été marquées individuellement et replacées dans leur colonie d'origine ( $\mathrm{N}=400$ par colonie). Leur activité et leur répartition spatiale par rapport à la reine ont été enregistrées durant 24 jours. $17,8 \% \pm$ $11,2 \%$ des ouvrières marquées $(\mathrm{N}=332)$ ont pénétré dans des colonies étrangères (Tab. I). Le comportement et la répartition spatiale des ouvrières du Cap ayant dérivé était significativement différent de celui des ouvrières de la même classe d'âge qui n'avaient pas dérivé (Tab. II). Les premières étaient significativement plus inactives et se tenaient plus souvent plus loin de la reine (Tab. II). Les résultas montrent que les ouvrières de l'Abeille du Cap qui ont dérivé présentent un comportement qui les prédisposent au parasitisme social.

Apis mellifera capensis / dérive / parasitisme social / reproduction des ouvrières

Zusammenfassung - Das Verhalten von verflogenen Arbeiterinnen der Kaphonigbiene (Apis mellifera capensis): Prädisposition für Sozialparasitimus? Arbeiterinnen der Kaphonigbiene, Apis mellifera capensis Escholtz, sind fakultative Sozialparasiten und Verflug ist ein Mechanismus zur Wirtsfindung. Es ist nur wenig bekannt über das Verhalten von verflogenen Bienen in ihren neuen Wirtsvölkern. Die Aktivität und die räumliche Verteilung im Volk können eine Rolle für den Sozialparasitismus durch legende Arbeiterinnen spielen, da inaktive Arbeiterinnen eine längere Lebensdauer zeigen und Bienen, die sich weiter entfernt von der Königin aufhalten, eine stärkere Pheromonentwicklung aufweisen. Die Aktivität und die räumliche Verteilung in Relation zur Königin von verflogenen und nicht verflogenen $A$. $m$. capensis Arbeiterinnen wurde in fünf Beobachtungsstöcken erfasst ( 3000 Arbeiterinnen pro Volk). Dazu wurden frisch geschlüpfte Arbeiterinnen individuell markiert und in ihre Ursprungsvölker eingesetzt $(\mathrm{N}=400$ je Volk). Die Aktivität und die räumliche Verteilung der markierten Bienen zur Königin wurden für 24 Tage erfasst. 17,8 \% $\pm 11,2 \%$ der markierten Arbeiterinnen $(\mathrm{N}=332)$ verflogen sich in fremde Völker (Tab. I). Das Verhalten und die räumliche Verteilung von verflogenen Kaparbeiterinnen unterschied sich signifikant von nicht verflogenen Bienen aus der selben Alterskohorte (Tab. II). Verflogene Arbeiterinnen waren signifikant inaktiver und häufiger weiter entfernt von der Königin (Tab. II). Die Ergebnisse deuten daraufhin, dass verflogene Arbeiterinnen der Kaphonigbiene Verhaltensweisen zeigen, die für Sozialparasitismus prädisponieren.

\section{Apis mellifera capensis / Arbeiterinnenrepro- duktion / Honigbiene / Sozialparasitismus / Verflug}

\section{REFERENCES}

Free J.B. (1958) The drifting of honeybees, J. Agric Sci. 51, 294-306.

Hillesheim E., Koeniger N., Moritz R.F.A. (1989) Colony performance in honeybees (Apis mellifera capensis Esch.) depends on the proportion of subordinate and dominant workers, Behav. Ecol. Sociobiol. 24, 291-294.

Moritz R.F.A., Kryger P. (1994) Self organisation of circadian rhythms in groups of honeybees (Apis mellifera L.), Behav. Ecol. Sociobiol. 34, 211215.

Moritz R.F.A., Crewe R.M., Hepburn H.R. (2001) Attraction and repellence of workers by the honeybee queen (Apis mellifera L.), Ethology 107, 465-477.

Moritz R.F.A., Crewe R.M., Hepburn H.R. (2002) Queen evasion and mandibular gland secretion of honeybee workers (Apis mellifera L.), Insectes Soc. 49, 86-91.

Neumann P., Hepburn H.R. (2002) Behavioural basis for social parasitism of Cape honeybees (Apis mellifera capensis Esch.), Apidologie 33, 165192.

Neumann P., Moritz R.F.A. (2002) The Cape honeybee phenomenon: the evolution of a social parasite in real time?, Behav. Ecol. Sociobiol. 52, 271-281.

Neumann P., Moritz R.F.A., Mautz D. (2000). Colony evaluation is not affected by drifting of drone and worker honeybees (Apis mellifera L.) at a performance testing apiary, Apidologie 31, 6779.

Neumann P., Pirk C.W.W., Hepburn H.R., Radloff S.E. (2001a) A scientific note on the natural merger of two honeybee colonies (Apis mellifera capensis), Apidologie 32, 113-114.

Neumann P., Radloff S.E., Moritz R.F.A., Hepburn H.R., Reece S.L. (2001b) Social parasitism by honeybee workers (Apis mellifera capensis Escholtz): host finding and resistance of hybrid host colonies, Behav. Ecol. 12, 419-42.

Neumann P., Pirk C.W.W., Hepburn H.R., Moritz R.F.A. (2003) Spatial differences in worker policing facilitate social parasitism of Cape honeybee workers (Apis mellifera capensis Esch.) in queenright host colonies, Insectes Soc. 50, 109-112. 
Pfeiffer K.J., Crailsheim K. (1998) Drifting of honeybees, Insectes Soc. 45, 151-167.

Pfeiffer K.J., Crailsheim K. (1999) The behaviour of drifted nurse honey bees, Insectes Soc. 46, 34-40.

Rauschmayer F. (1928) Das Verfliegen der Bienen und die optische Orientierung am Bienenstand, Arch. Bienenkd. 9, 249-322.

Reece S.L. (2002) A scientific note on the ovarial and pheromonal development of drifted and nondrifted Cape honeybee workers (Apis mellifera capensis), Apidologie 33 (2002) 213-214.
Seeley T. (1998) Thoughts on information and integration in honeybee colonies, Apidologie 29, $67-80$.

Wossler T.C. (2002) Pheromonal deceit by honeybee workers leads to reproductive anarchy in Apis mellifera scutellata colonies, Apidologie 33, 139-163.

Woyke J. (1984) Correlations and interactions between population, length of worker life and honey production by honeybees in temperate region, J. Apic. Res. 23, 148-154. 